\title{
Verismo opera: \\ how bel canto technique protected the voices of its singers \\ BY
}

Zeyu Chen

\author{
An exegesis \\ submitted to the Victoria University of Wellington \\ in partial fulfilment of the requirements for the degree of \\ Master of Musical Arts
}

Victoria University of Wellington

2020 Year of Submission 


\begin{abstract}
Verismo is a style of opera composition that was influenced by a significant movement in Italian literature from the end of the nineteenth century to the beginning of the twentieth century. It is characterised by the true-to-life portrayal of rural or urban poverty, often showing a robust regional lifestyle as well as serving as the introduction to the region's representative songs and dances. ${ }^{1}$ Historically, the singing of verismo opera posed some problems for singers in regards to their stamina and the longevity of their career. As a student, I attempted to sing this type of music, but I felt unable to sing it well; my difficulties and the problems associated with the performance of verismo, therefore, fascinated me. Rationalising that proper vocal technique was the answer to these problems, I then concentrated on long-term systematic bel canto training in China and New Zealand.
\end{abstract}

In most cases, the study of bel canto technique is a fundamental part of the process of learning vocal music for classical singers. In addition to laying out the background of verismo and bel canto, my exegesis demonstrates how singers can learn to sing verismo opera well without damaging their voices, which will help them extend their stamina and the length of their career. I especially investigate the differing use of the body needed for singing each type of music. Researching bel canto, I have listened to different singers' recordings and have written short critiques of their voices, focusing on how they developed bel canto to sing verismo. I have focused on bel canto and verismo works for my repertoire and can apply the techniques safely based on bel canto training. To articulate this knowledge, I take three different arias (one bel canto aria, two verismo arias) as case studies to analyse, to demonstrate the points I want to make. In addition, as a native Mandarin Chinese speaker, I focus on how Mandarin native speakers deal with singing Italian, and I articulate techniques to help other Mandarin speakers learn bel canto. Overall, my research will have practical and

\footnotetext{
${ }^{1}$ Jane Bellingham. "Verismo." The Oxford Companion to Music (2011): The Oxford Companion to Music. Web.
} 
artistic value for younger students in helping them to understand the challenges of singing verismo opera. 


\section{Table of Contents}

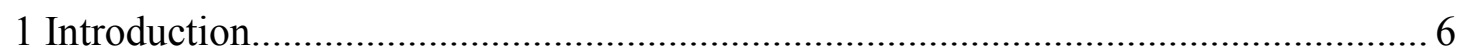

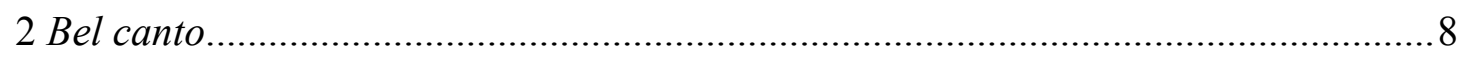

2.1 Concepts and attributes of bel canto singing ............................................ 8

2.2 Representative composers ....................................................................... 12

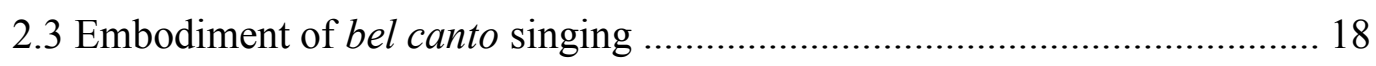

3 Chinese Mandarin native speakers sing bel canto................................................. 18

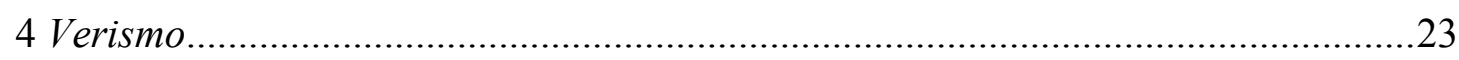

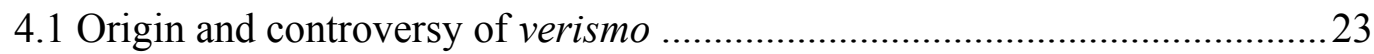

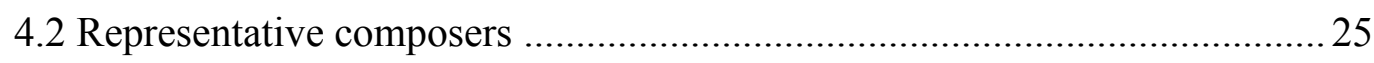

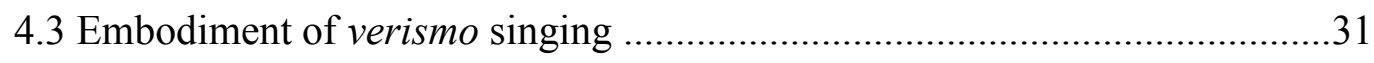

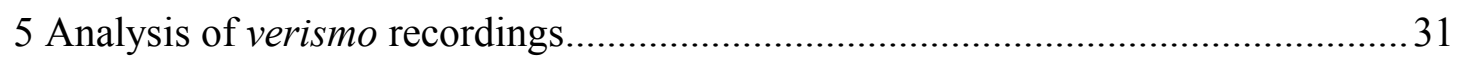

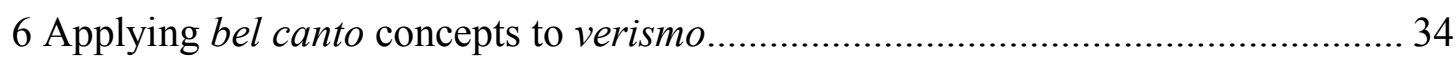

6.1 Case study of Don Pasquale 'Quel guardo il cavaliere'................................ 35

6.2 Case study of I Pagliacci 'Stridono lassù' ................................................... 36

6.3 Case study of Madama Butterfly 'Un bel di, vedremo' ............................... 38

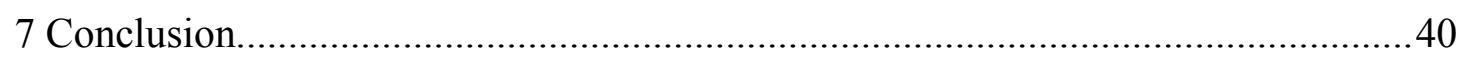

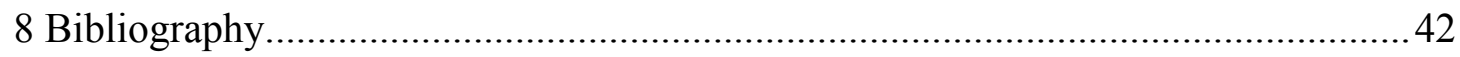

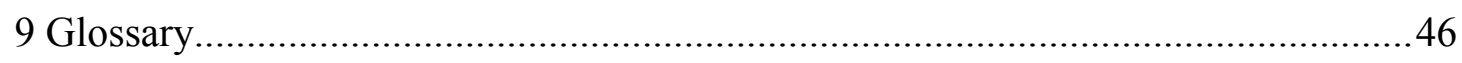




\section{$\underline{\text { Acknowledgements }}$}

I would first like to thank my thesis supervisor and vocal teacher, Dr Margaret Medlyn, Head of Classical Voice Performance at the New Zealand School of Music, Te Koki at the Victoria University of Wellington. She always supports and helps me, which makes me learn a lot of vocal techniques and theoretical knowledge. She can identify my problems and help me solve them.

Thanks to my vocal coaches Bruce Greenfield and David Barnard for teaching me how to learn a new song properly and some incredible vocal techniques.

Thanks to the teachers at Student Learning. They helped me improve my English and gave me good suggestions for my exegesis.

Thanks to my family for their encouragement and support. Special thanks to my mom for always supporting my singing career. When I was in trouble and wanted to give up, she encouraged me: "If studying music makes you miserable, give it up. Learn something else that makes you happy. You chose to study music because you love music." 


\section{Introduction}

This chapter presents an overview of the significance of the musical histories of bel canto and verismo, and why their characteristics are so individual to each technique.

Western classical music singing training in China, where I was a vocal music student from 2009, includes an essential emphasis on bel canto training. As a developing singer, I am eager to advance my understanding of the bel canto method and its emphasis on specific technical skills. Watching some of Puccini's operas at the beginning of my study in China, I was most impressed by his last opera Turandot, where a traditional Chinese music melody was contained in the music. Turandot is an opera with Oriental elements and Puccini had adapted the melody from the Chinese folk song "Jasmine flower". Throughout the opera, Puccini composed different variations on this melody according to the various scenes of the story: at times its original charm and softness were utterly gone, and it sounded sad and desolate as background music. Another opera with Oriental elements, Madama Butterfly, had Japanese songs adopted by Puccini within the score. These two operas fascinated me, and I became very interested in Puccini's operas, leading me to discover that many of his operas were a part of an operatic movement called verismo. Following this discovery, I became very interested in verismo opera and the problems associated with its performance.

Verismo, as a music style, encourages reliance on the voice in the extremes of the vocal range that conveys the intensity of highly emotional states, heightening dramatic situations; it is only suitable for certain voice types and temperaments. ${ }^{2}$ This will be examined further in Chapter 4 . The style is also characterised by the requirement for sung dramatic recitation, declamato, in the middle and low range, which poses severe risks for careless, overly emotional singers whose voices are too

${ }^{2}$ Craig Timberlake. "Verismo Voices." Journal of Singing - the Official Journal of the National Association of Teachers of Singing 53, no. 1 (09, 1996): 33-35. https://search.proquest.com/docview/1399506?accountid=14782. 
lyrical to withstand the pressure. ${ }^{3}$ Some young singers who are attracted to the music and emotion, mistakenly attempt to sing verismo repertoire when their voices are immature. After possibly sustaining some vocal injuries, they realise they need to be careful, and the renewed interest in bel canto training is stimulated.

Bel canto is an old method of singing, based on the teachings of the sixteenth-century masters and their famous students, including the castrati. Generally, the study of bel canto is a fundamental part of the process of learning vocal music techniques for most classical singers today. This technique was developed in an age without microphones, and to assist in projection, bel canto training, the method of the composer's writing, and the sound design of the opera house made it possible to perform without electroacoustic amplification. In the theatres, without amplification, the audience expected to hear the projected vocal sound from the first row to the last row. This is entirely different from other singing methods now that rely on electroacoustic amplification, such as musical theatre.

To illustrate how vital the body is, I also spend some time articulating the importance of the use of it in singing, and particularly the differences in the engagement of the embodiment for the different types of music. In Chapter 2, I will investigate the concepts and attributes of bel canto. Importantly, I found that different scholars have different definitions of bel canto, and I suggest ways to reconcile conflicting advice. Next, I will introduce three representative composers of bel canto and how they composed for singers. Following this in Chapter 3, I will focus on how Mandarin native speakers deal with sung Italian, and I will offer ideas to help other Mandarin speakers learn bel canto. Then, in Chapter 4, I will explore the origin and controversy of verismo and introduce how three representative composers contributed to verismo. In Chapter 5, I will analyse selected singers' verismo works to explore how bel canto

\footnotetext{
${ }^{3}$ Craig Timberlake. "Verismo Voices." Journal of Singing - the Official Journal of the National Association of Teachers of Singing 53, no. 1 (09, 1996): 33-35. https://search.proquest.com/docview/1399506?accountid=14782.
} 
vocal training has provided the verismo composers and singers with well-trained voices for them to sing verismo. I examine their recordings and analyse their vocal techniques.

Finally, in Chapter 6, in order to demonstrate the application of bel canto concepts to verismo, three different arias (one bel canto aria, two verismo arias) will be taken as examples to investigate and articulate the difficulties in performance, both technical and dramatic. For each of these case studies, I will provide a brief story synopsis and also describe my learning process of them and how I use bel canto techniques to sing verismo. I am currently undergoing advanced bel canto training, and I have devised a recital to demonstrate my abilities which is part of this MMA. Therefore, in the process of learning these pieces, my understanding and experience of these female characters will help me collect relevant information to support my research.

To conclude, I will lay out how my research has helped clarify my suggestion that training in the bel canto technique is essential, but particularly when singing challenging and emotionally involved music. I have found and analysed well-recorded samples to support the application of such techniques. I have built my final recital around selected songs and arias that allow me to show what I have learnt to do technically to protect my vocal apparatus, but also to express the music and text of the composer and librettist.

\section{Bel canto}

\subsection{Concepts and attributes of bel canto singing}

The term bel canto has two broad meanings that people acknowledge: the most widely recognised is that it means of "beautiful singing" in Italian, the other, the style of opera and operatic composition. According to Willi Apel's Harvard Dictionary of Music, bel canto refers to "the Italian vocal technique of the eighteenth century, with its emphasis on the beauty of sound and the brilliancy of performance rather than 
dramatic expression or romantic emotion". ${ }^{4}$ On the other hand, Rodolfo Celletti pointed out in A History of Bel Canto that the term bel canto itself was unknown in the seventeenth and eighteenth centuries. He believes that the original purpose of bel canto was used to establish a beautiful fantasy world, fairytale opera scenes, to show off the high-pitched singer's unusual timbre, and delicate and exquisite vocal performance, as a kind of contrast to ordinary and vulgar daily life. ${ }^{5}$ However, Robert Toft, a professor of musicology and specialist in historical performance practice at the Western University in London, Canada, retrospectively defines bel canto as "a comprehensive label for vocal performance between c. 1600 and c. 1850 ”. He also stressed that " the term did not begin to represent a "style" of singing until the second half of the nineteenth century". From what has been discussed above, I will use the term bel canto in this exegesis as it refers to the beautiful, operatic singing from eighteenth-century Italy.

In the history of Western music, the Italian style of singing was significant for a variety of national styles of singing in the Baroque age. ${ }^{6}$ Many people learned the Italian style not only from the conservatories of Naples or other Italian cities but also from family members who passed on their traditions from generation to generation, and from the big singing schools for the castrati. ${ }^{7}$ The term 'castrato' refers to a male singer who was castrated as a boy to preserve his vocal folds in the soprano or alto range after his body, and particularly the chest and lungs developed to adult size. To retain this extraordinary sound, castration was practised in Italy from the sixteenth to

\footnotetext{
${ }^{4}$ Willi Apel. Harvard Dictionary of Music, 82. 2d ed., rev. and enl. Cambridge, Mass: Belknap Press of Harvard University Press, n.d.

${ }^{5}$ Martha Elliott. "The Early Baroque." In Singing in Style: A Guide to Vocal Performance Practices, 21-22. Yale University Press, 2006. http://www.jstor.org/stable/j.ctt32brkx.5. ${ }^{6}$ Julianne Baird. "The Bel Canto Singing Style." In A Performer's Guide to Seventeenth-Century Music, edited by Carter Stewart, by Kite-Powell Jeffery, 31-43. Indiana University Press, 2012. http://www.jstor.org/stable/j.ctt16gzcwn.9. ${ }^{7}$ Martha Elliott. "The Early Baroque." In Singing in Style: A Guide to Vocal Performance Practices, 20-21. Yale University Press, 2006. http://www.jstor.org/stable/j.ctt32brkx.5.
} 
the eighteenth centuries and continued into the nineteenth century. From the late sixteenth century until 1903, castrati were members of the Sistine Chapel choir and were prominent in operas throughout the seventeenth and eighteenth centuries. The most famous castrati of the eighteenth century included Senesino (Francesco Bernardi, d. ca. 1750), Caffarelli (Gaetano Majorano, 1710 - 83), and Farinelli (Carlo Broschi, 1705 - 82). The last famous castrato was Giovanni Battista Velluti $\left(1780\right.$ - 1861). ${ }^{8}$ In general, most of the Italian Baroque singers were extremely well-trained musicians, masters of an instrument, composition and theory and after their training, singers were often associated with a church or court; because of restrictions imposed by that employment, they could only sing at private parties or to entertain themselves. ${ }^{9}$ According to Martha Elliott, "The Early Baroque." In Singing in Style: A Guide to Vocal Performance Practices, "The classical bel canto style crystallized in the late seventeenth century, when musical considerations triumphed over the text-dominated style of the early part of the century." ${ }^{10}$ In addition, Italian opera had become fashionable, trained singers from Italy were prevalent throughout Europe, and it became essential for all singers to have a proper bel canto technique. ${ }^{11}$

Though all of the teaching was governed by a personal preference for a particular sound, the teaching of singing before the nineteenth century generally promoted the vocal characteristics of the tonal concepts desired at the time by both artists and

8 "Castrato [It.]." In The Harvard Dictionary of Music, edited by Don Michael Randel. 4th ed. Harvard University Press, 2003.

http://helicon.vuw.ac.nz/login?url=https://search.credoreference.com/content/entry/ha rvdictmusic/castrato_it/0?institutionId $=5378$

${ }^{9}$ Martha Elliott. "The Early Baroque." In Singing in Style: A Guide to Vocal Performance Practices, 20-21. Yale University Press, 2006. http://www.jstor.org/stable/j.ctt32brkx.5.

${ }^{10}$ Julianne Baird. "The Bel Canto Singing Style." In A Performer's Guide to Seventeenth-Century Music, edited by Carter Stewart, by Kite-Powell Jeffery, 31. Indiana University Press, 2012. http://www.jstor.org/stable/j.ctt16gzcwn.9. ${ }^{11}$ Julianne Baird. "The Bel Canto Singing Style." In A Performer's Guide to Seventeenth-Century Music, edited by Carter Stewart, by Kite-Powell Jeffery, 31. Indiana University Press, 2012. http://www.jstor.org/stable/j.ctt16gzcwn.9. 
composers. Today these concepts are usually attributed to the "Italian style" of singing, such as legato, sostenuto, coloratura and register unity. For Mozart, the Italian opera style of singing and the form was a standard. The vocal techniques, particularly the messa di voce, in which the singer grows alternatively stronger and weaker on a single note and has perfect tonal balance, are considered a test for singers of any level. As well as these techniques, there was the expectation of being able to execute complicated ornamentation that are not often written on the sheet music: singers needed to train to write and perform the decorations that they were often expected to add to the music, the ornaments or fioriture, especially to the da capo section of music. Though old Italian texts of the sixteenth century require specialised knowledge to interpret, and there are many different interpretations of stylistic considerations, decorative expectations, and issues dealing with text and rhythm, singers today still have the freedom to vary the rhythm and pitch of the music. ${ }^{12}$ With this information and as an example, I designed some ornaments for specific arias. Here is an example of the da capo section of Alcina's aria 'Tornami a vagheggiar' from opera Alcina where I chose ornamentation to use that suited my voice.

(Figures.1 and 2)

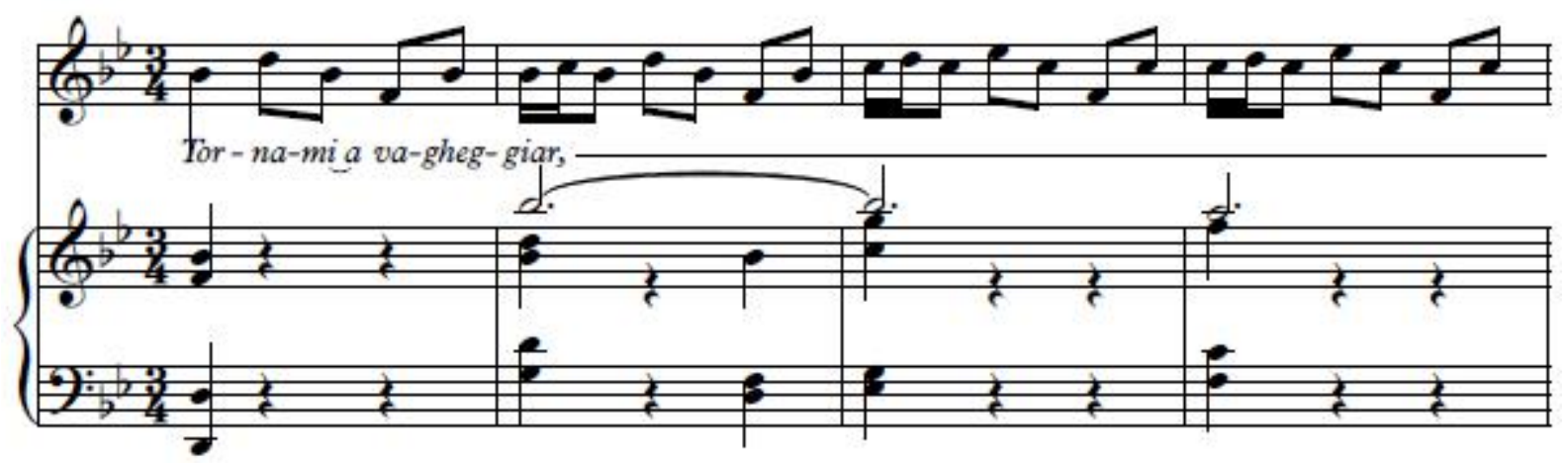

Figure 1 "Tornami a vagheggiar"

\footnotetext{
12 Robert Toft, Bel Canto: A Performer's Guide, (USA: Oxford University Press, 2012) 3-4; Margaret Medlyn Embodying Voice: Singing Verdi, Singing Wagner, (New York, Routledge, 2018) 44-45.
} 


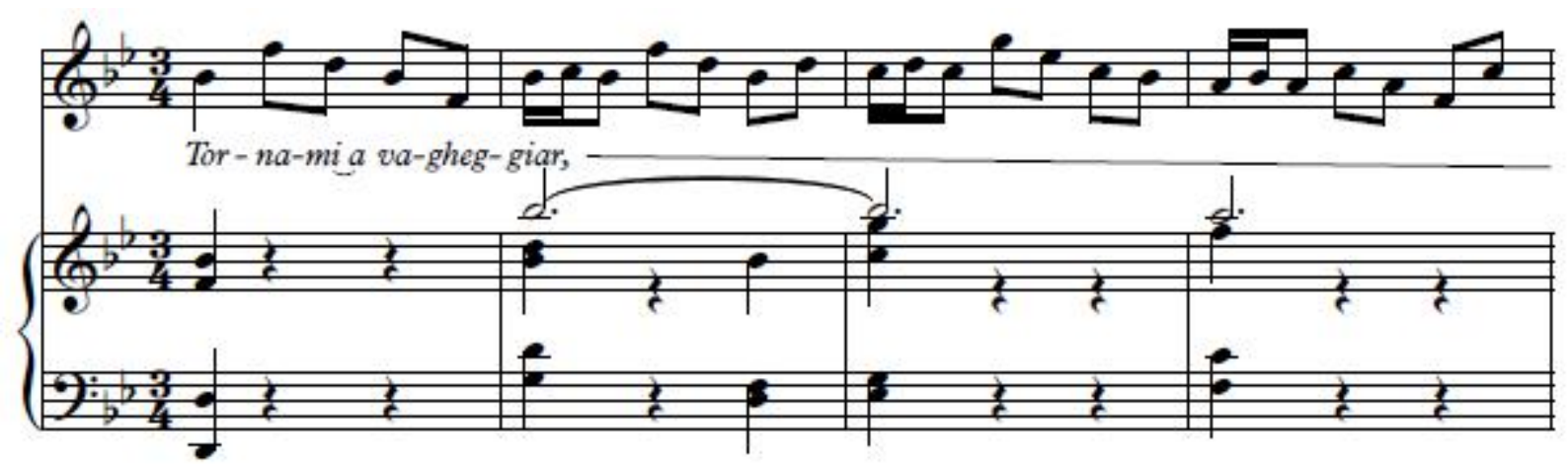

Figure 2 The da capo section of "Tornami a vagheggiar"

As the times changed, many composers preferred to write their ornamentation out on the score. In this way, they did not have their music changed too much and had more control of their music. Despite this, I suggest that it is still necessary to train singers to write and execute ornaments. Different ornaments created by different singers not only show the singers' singing techniques but also bring different auditory feelings to the audience in the same song, and can imply different characterisation and embodiments.

\subsection{Representative composers}

Gioachino Rossini (1792-1868), Gaetano Donizetti (1797-1848) and Vincenzo Bellini (1801-1835) were prominent representatives of bel canto vocal music in the beginning half of the nineteenth century. This section is a brief introduction to these composers, how they contributed to the bel canto movement and the particular characteristics of their vocal music.

Gioachino Rossini was born in a musical family in Pesaro. His father was a trumpeter and horn player, and his mother was a singer. Because of these advantages, he was encouraged in all musical activities: singing in churches and playing the harpsichord, piano, viola, cello, and horn as a child. He entered Bologna's Liceo Musicale (Bologna's music academy) at the age of 14, where he mainly composed hymns. Nevertheless, in 1810, he left Liceo and moved to Venice where he soon wrote his first comic opera, La cambiale di matrimonio (The Bill of Marriage), which was a 
great success and has occasionally been revived. From 1812 onwards, he created dramatic works at an astonishing rate: between 1810 and 1829, he produced 39 operas, comic and serious, that changed Italian opera and fundamentally changed the course of French opera. ${ }^{13}$ The political turmoil sweeping Europe affected him, and in 1829, at the age of 37 , he retired early from opera writing: he had also suffered from a series of unbearable illnesses such as the inflammation of the intestine, which weakened his health. $^{14}$

For the time, Rossini's music was entirely revolutionary and new. The vibrancy of the rhythm, the strong orchestral structure and the dynamic melodies were some of the elements of his new style. He not only changed the music but also helped form the operatic style of today, developing the importance of the comic opera and tailored his music to the virtuoso singers who were available and interested in singing his music. By developing theatrical communication in expanding the importance of specific character roles, he changed the structure of operas. Julian Budden comments that Rossini developed a certain compositional structure, and John Rosselli notes that Rossini's work with the aria and cabaletta allowed emotion to be released. This could be quite explosive with the kinetic energy moving from one structure eg., the aria, to the duet, to the large ensemble. ${ }^{15}$ These fast-paced works require singers to have strong vocal techniques particularly for the heroic and challenging male roles, especially tenor, that were rare among other composers.

\footnotetext{
${ }^{13}$ Rossini Gioacchino (Antonio). From Britannica Concise Encyclopedia, by Encyclopaedia Britannica. Britannica Digital Learning, 2017.

http://helicon.vuw.ac.nz/login?url=https://search.credoreference.com/content/entry/eb concise/rossini_gioacchino_antonio/0?institutionId $=5378$

${ }^{14}$ Richard Osborne. Rossini: His Life and Works. 2nd ed. New York: Oxford University Press, 2007. Oxford Scholarship Online, 2011. doi: 10.1093/acprof:oso/9780195181296.001.0001.

15 Julian Budden The New Grove Masters of Italian Opera (with others), New York, W.W. Norton, 1981; John Rosselli, Music and Musicians in Nineteenth-Century Italy. Portland (OR): Amadeus Press, 1991.
} 
In comparison, Gaetano Donizetti was born in very ordinary circumstances

in Bergamo. His early contact with music was facilitated by his first composition teacher and lifelong mentor, Simon Mayr. As Rossini was his primary influence, he based his melodic style on Rossini's, with rich harmonies and orchestral music. As a consequence, Donizetti spent the first decade of his career, from 1820, composing operas (both comic and serious) that were mostly in the unabashedly "Rossinian" style. However, his mature style is recognised as beginning with Anna Bolena (1830), an opera that brought him new national and international fame. In formal terms, Anna Bolena does show a distinctiveness from the Rossini style, especially by investing more considerable emotional importance in heightened recitative, but the opera's basic singing style remained old-fashioned, as it continued to use Rossinian ornamentation for all characters. ${ }^{16}$ Donizetti wrote a large number of orchestral, chamber, choral and vocal works, but except his 65 operas, there were few other significant works. ${ }^{17}$

Donizetti developed a new style of music drama that was more theatrical than earlier composers. He had a keen sense of the dramatic and was good at using music to indicate the shape of the thinking of the protagonists, vividly depicting the inner world and the emotional life of the characters. He was literate and enjoyed being part of the creation of his librettos and hence his music is melodic and fluent with the use of accompaniment to illuminate the meaning of the words. He chose to write music for intensely committed artists who were good actors, adept at dramatic changes and interested in developing leading roles. His roles for tenors such as Gilbert Duprez helped the developing and changing style of their singing. ${ }^{18} \mathrm{He}$ wrote out the singers'

${ }^{16}$ Carolyn Abbate, and Roger Parker. A History of Opera : The Last Four Hundred Years / Carolyn Abbate and Roger Parker. Second ed. 2015. Print.221.

17 "Donizetti." In Opera: The Great Composers and their Masterworks, by Joyce Bourne. Octopus Publishing Group, 2008.

http://helicon.vuw.ac.nz/login?url=https://search.credoreference.com/content/entry/op gopera/donizetti/0?institutionId $=5378$

${ }^{18}$ French tenor, credited with introducing the chest-voice high C (as Arnold at the Italian première of Guillaume Tell, to Rossini's discomfiture) as part of the package of the tenore di forza. He appeared as a boy treble at the Comédie Française, and as a 
impromptu parts, cadenzas and ornamentation, which helped to prevent them from showing off too much and so disturbing the overall effect.

Vincenzo Bellini was the last of the three bel canto composers to be born and also the shortest-lived - he died in Paris at the age of 33. He was born in Catania, at the time a part of the Kingdom of Sicily. His earliest musical education came from his family his father and grandfather were both musicians. At 18, Bellini entered the San Sebastiano conservatory of music in Naples, where he was influenced by the school's director, Niccol' Zingarelli, an older composer and violinist, who introduced Bellini to old Neapolitan composers as well as Haydn and Mozart. He encouraged Bellini to make music based on how he felt "-- from the heart, with melody the most crucial aspect." 19 This led to beautiful melodies such as Norma's aria "Casta diva", from Norma, where long, elegant lines and ornate decoration requires a very flexible sound and dramatic ability. Although Rossini's music dominated Naples at this time, Bellini did not hear Rossini's operas until 1824 because his teachers thought it essential that he developed his skills without being influenced by the older composer. ${ }^{20}$

Nevertheless, Bellini's early operas, like Donizetti's, were inevitably influenced by Rossini, although Bellini's teachers in Naples were opposed to him. For them,

tenor at 18. After several years in Italy, studying and performing (notably as the first Edgardo in Lucia di Lammermoor), he returned to Paris as Arnold (1837), creating further roles in operas by Berlioz (Benvenuto Cellini), Donizetti and Verdi. He also wrote operas and memoirs. "Duprez, Gilbert (Louis)." In The New Penguin

Dictionary of Music, by Paul Griffiths. Penguin, 2006.

http://helicon.vuw.ac.nz/login?url=https://search.credoreference.com/content/entry/pe nguinmusic/duprez_gilbert_louis/0?institutionId $=5378$

19 "Bellini." In Opera: The Great Composers and their Masterworks, by Joyce Bourne. Octopus Publishing Group, 2008.

http://helicon.vuw.ac.nz/login?url=https://search.credoreference.com/content/entry/op gopera/bellini/0?institutionId $=5378$

20 "Bellini." In Opera: The Great Composers and their Masterworks, by Joyce Bourne. Octopus Publishing Group, 2008.

http://helicon.vuw.ac.nz/login?url=https://search.credoreference.com/content/entry/op gopera/bellini/0?institutionId $=5378$ 
Rossini's orchestral work was too contrived and refined, even too 'German'. However, Il pirata (The Pirate, 1827) and La straniera (The Stranger, 1829) showed that Bellini had something different to offer. Standard terms called "romantic" and even "philosophical" by contemporary critics often had little to do with the plots. Although the Gothic style influenced both operas, and several of Donizetti's operas, Bellini's highly individual writing style was considered "romantic". ${ }^{21}$

Bellini's contribution to the operatic genre was to imagine and compose melodies with long vocal lines that could allow the voice "to break hearts" with the quality of the sound and breath. ${ }^{22} \mathrm{He}$ specialised in exploring the limits of human suffering and the psyche and setting those emotions to music. However, Bellini wrote much more slowly than Donizetti. He produced just one opera a year on average in his short career, and he would not tolerate any last-minute rush. His preferred approach was to be heavily involved in the writing of scripts, often insisting on revisions to make sure the text was what he needed for music. Given his slow production, he could not match Donizetti's overall popularity and influence; but several of his operas immediately became classics and remain so to this day. ${ }^{23}$

Bellini and his librettists, most often Felice Romani, preferred intensely affectionate or emotionally charged dramas that featured ethical and tragic associations. ${ }^{24}$ Bellini's

${ }^{21}$ That era of music following the Classical era and ending around 1900. The compositions of the Romantic era are characterized by great, large ensembles, great dynamic fluctuations from fortississimo (fff) to pianississimo (ppp), less tonal and melodic tunes, more discordant, atonal pieces, and immense, long compositions. The piano is a prominent instrument of the Romantic era. Major Romantic composers include: Frédéric Chopin, Franz Liszt, Robert Schumann, Richard Wagner, Johannes Brahms, Hector Berlioz, Franz Schubert, etc. https://dictionary.onmusic.org/terms/2936-romantic

${ }^{22}$ Carolyn Abbate, and Roger Parker. A History of Opera : The Last Four Hundred Years / Carolyn Abbate and Roger Parker. Second ed. 2015. Print.232-233.

${ }^{23}$ Carolyn Abbate, and Roger Parker. A History of Opera: The Last Four Hundred Years / Carolyn Abbate and Roger Parker. Second ed. 2015. Print.233.

${ }^{24} \mathrm{https}: / /$ www.britannica.com/art/opera-music 
works are melodic and fluid, and his works link music and language closely together, featuring lyrical melodies and beautiful harmonies. His works are challenging for the singer: vocal control, intensity, timbre and the performance are paramount: they are an excellent way for the singer to perfect their vocal technique. He developed the use of repetition, long melodies and the power of declamation, in operas such as $I$ Puritani. Moreover, he wrote vocal music for certain singers with their exceptional vocal and dramatic abilities, such as Giuditta Pasta.

Despite the fame of Rossini, Bellini, Donizetti and other lesser composers, singers continuously rearranged their numbers to suit their musical preferences and vocal abilities. They also used a method called puntatura, in which they kept the music at the same key but adjusted the notes to suit their range. This may have included lowering exceptionally high notes, or, more commonly, raising particularly low notes higher. This was very annoying for the composers as they preferred to hear their music as they wrote it. However, to control this habit, from the 1840 s, the young Verdi started to pay more and more attention to the dramatic and musical flow of the whole opera, insisting that the creation of all such changes was his own, rather than letting the singer decide, and finally started to develop the concept of copyright. ${ }^{25}$

To sum up, the above three representative composers of bel canto inherited the traditional Italian style and made essential innovations, so enriching the vocal music of the nineteenth century. Their methods of composition provided with an evolving structure for later composers to further develop. Their operas are graphic expositions of emotions that were unable to be articulated in their contemporary society.

Moreover, they focussed on the stories of women. They expressed their emotions in a way that had not been expressed before: the heroine carries the emotional weight of the story as she is harried by unstable, weak or violent men.

\footnotetext{
${ }^{25}$ Martha Elliott. "Italian Bel Canto." In Singing in Style: A Guide to Vocal Performance Practices, 135-136. Yale University Press, 2006. http://www.jstor.org/stable/j.ctt32brkx.8.
} 


\subsection{Embodiment of bel canto singing}

Generally, the singing of bel canto operas requires beautiful seamless sound with no sign of visible effort on the part of the singer. In addition, the form of the operas-arias, cabalettas and choruses are often of such vocal difficulty that they form a vocal display where the voice is most important. As the words are generally very simple, the sound carries the emotional content: the voice is put to the service of the mind's psychological torture. The voice should describe changing emotions, even though the words might be repeated. This requires the singer's complete physical and mental concentration and much practice to train the bodily engagement. As singers, we spend much time training muscles in fine movements, and also engaging larger muscles to sustain longer notes. My voice teacher Margaret Medlyn often asked me to draw an emotional map of a character's journey: I think that this is beneficial, and I use this method in most arias. For example, in 'O rendetemi la speme...Qui la voce' from $I$ puritani, 'O rendetemi la speme...Qui la voce' is repeated many times at the beginning of this aria. Elvira's emotions could be sadness, disappointment, resentment and so on. Her emotions in this aria are complicated, so the singer is required to choose different feelings to express the created meaning of the repeated lyrics. Therefore, a singer should construct Elvira's emotional journey according to their imagination when practising.

It can seem that singing bel canto operas is not as physical as singing verismo. However, the work done by the body is so well practised in that it is hidden and often the singer needs just to stand and sing - there is no distracting scenery or action, so the audience's attention is solely on the singer.

\section{Chinese Mandarin native speakers sing bel canto}

The accuracy of pronunciation is crucial for singing bel canto as most works are written in Italian. This section focuses on how Chinese Mandarin native speakers deal 
with singing Italian and contains suggestions and Italian pronunciation skills on how to help other Mandarin speakers learn bel canto from the lessons I have learnt.

Bel canto was introduced into China in the early twentieth century. At that time, there were no professional music schools in China who offered bel canto teaching. However, in 1927, Cai Yuanpei (a Chinese philosopher and politician) and Xiao Youmei (a Chinese music educator and composer) founded a professional music college in Shanghai, and began to hire some vocal music educators, who had returned from studying abroad, for voice teaching in the school. Among them were vocal teachers, Yu Yuxuan and Zhou Xiaoyan, who specialised in teaching bel canto. As their influence and fame spread, the bel canto technique was gradually preferred by students of singing. Later, professional music conservatories and university music departments in China were established, which had a beneficial effect on the development of bel canto music in China. ${ }^{26}$ Presently, there are not only music departments in some comprehensive universities but also ten conservatories of music in China. Although voice teachers have different teaching methods, most of them have studied abroad and come back to China from Italy, Germany and Russia. The teaching methods used by all of them are universally considered bel canto. Generally, students study with only one voice teacher during the entire four-year undergraduate period. During that period of study, in addition to vocal music lessons and music theory courses, students will have some language classes which mainly teach students pronunciation skills in singing: lyric diction.

As we have seen, bel canto articulation is based on the characteristics of the language structure of Italian pronunciation. In my experience, some Chinese vocal teachers tend to focus on vocal skills and not enough on language pronunciation. The Italian way of speaking naturally shapes the space inside the mouth to form the correct space

${ }^{26}$ Keke Pan, http://www.oxiang.com/music/20170813/61171.html 
needed for singing. There is the energy involved in its projection. ${ }^{27}$ Therefore, the clarity of Italian pronunciation and the energy required is conducive to singing well. Most Italian words end with a vowel sound that should be bright and round.

Chinese is very different from Italian. Each syllable in Chinese has its tone. Yin ping (the first tone) Yang ping (the second tone) Shang sheng (the third tone) and Qu sheng (the fourth tone) are four tones in Chinese to distinguish the meaning of the word. For example, the meaning of Chinese word 'shū' with Yin ping means 'book' in English; 'shú' with Yang ping means 'mature'; 'shǔ' with Shang sheng means 'count'; 'shù' with Qu sheng means 'tree'. Some Chinese words end in consonants like Italian words, for example, 'gāngqín' but the consonants at the end of the word do not need to be stressed. By contrast, some Italian words end with consonants sound should be emphasised. Some singers may lose consonants in words that end in consonants, such as 'ng' and 'n'. According to the rules of Italian pronunciation, they all need to be clearly pronounced. Also, there are long vowels sound in Italian but not in Chinese. This might not only impact how long vowels should be held but also change the meaning of words.

In Chinese, vowels and consonants are pronounced as one sound in a word without being separated, for example, “jiâa”. Therefore, some Italian words were often mispronounced by students, such as "mio", "mia" and "io". They should be pronounced individually for each syllable, with the emphasis on the correct vowel. The " $\mathrm{i}$ " in these words is a long sound, and its phonetic symbol in English is "i:". However, there is no such pronunciation rule in Chinese. As a result, Chinese students may not be accustomed to prolonging certain vowels in Italian. I suggest breaking down the beat into other beats to match the corresponding syllable but keeping the rhythm the same. (Figure.3)

${ }^{27}$ Johan Sundberg, The Science of the Singing Voice, Northern Illinois University Press 1987 


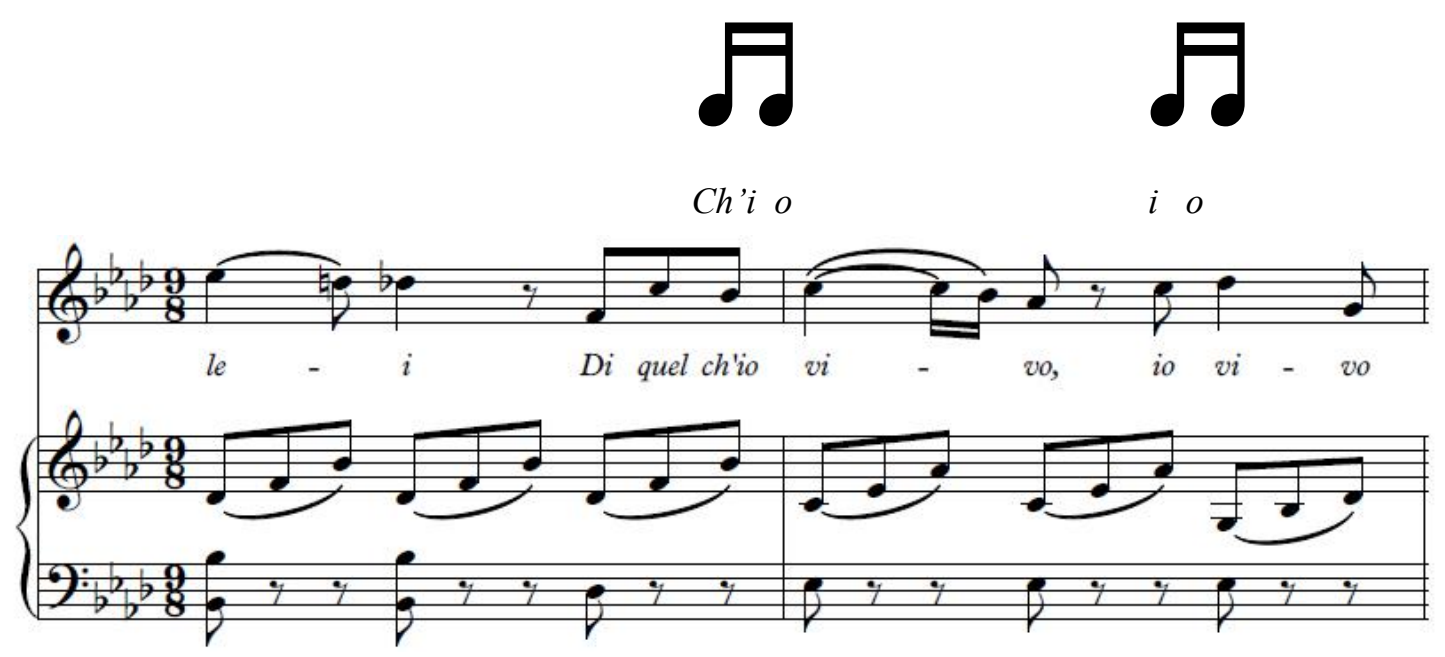

(Figure 3 "Ma rendi pur contento")

It is difficult for some singers to pronounce the sound of 'rolled'r. I suggest the singers say the Chinese phonetic alphabet "tì le" repeatedly from slow to fast. The tongue is relaxed during practice. After repeated practice, the sound of 'rolled'r will come out automatically.

It is helpful for native Chinese speakers to learn Italian if they can speak English. An English speaker may recognise many Italian words because both English and Italian come from Latin. However, although Italian and English use the same five vowels, there are seven related vowels in Italian. This is because both "e" and "o" come in two forms, open and closed. In the process of singing Italian songs, singers should keep the throat open and make use of the change of tongue position to make sure the vowels are clear. The tongue is a vital organ that affects our singing: to assist in focus, projection, open throat and clarity of diction. The middle of the tongue should be kept high, and out of the vocal tract while singing. ${ }^{28}$

I was required to keep the mid-tongue high by my vocal teachers and vocal coaches in the New Zealand School of Music. Like most singers, the first thing I do when I entered the practice room is to warm up my voice. First, I sing the five Italian basic vowels i, e, a, o, and u from the bass to the treble with some melodies. Sometimes I

${ }^{28}$ As related to me by Dr Margaret Medlyn. 
put "g" in front of the five vowels as gi, ge, ga, go and gu. The purpose of adding " $\mathrm{g}$ " is to keep the position of the mid-tongue high and forward. In this way, the vowels are much clearer.

In addition to correct pronunciation, understanding the meaning of each Italian word helps in singing well with the right emotion in the voice. Finding the meaning of each word can make learners fully understand music's structure, stress and mood. Not only that, but singers also need to know the background of the song and its composer, which helps them to choose the right emotion to express when singing. In China, many Italian bel canto scores are translated into Chinese and published, which makes it easy for voice students to learn standard Italian bel canto repertoire. With this help, most students usually do not look up the meaning of every Italian word, so they may not be able to interpret the meaning of what they sing. I advise that students look up the meaning of every word in an Italian dictionary because the translation on the score is sometimes not accurate. This also happens to some of the scores that are translated into English. By looking up the meaning of each word and knowing the background of the song and its composer, singers can express appropriate feelings of songs. After that, I suggest reciting the lyrics with emotion according to the rhythm of the music. To improve language sense and pronunciation, I recommend students regularly watch the articulation of native Italian singers, such as Luciano Pavarotti, Renata Tebaldi, Cecilia Bartoli, Mirella Freni and Renata Scotto.

The correct pronunciation of Italian plays a vital role when singing bel canto, no matter what native language the singer speaks. To form good singing habits, they can watch the positions of tongue and mouth in the mirror while practising. Singers need to know background, story outline and musical style in order to express the correct meaning of a song: they should listen to and watch different articulations of native Italian singers and combine their own singing experience to form their singing style. Moreover, using recording equipment to record their voice lessons, vocal coaching 
and practice as well as critically listening to the recordings is beneficial for singing Italian.

\section{Verismo}

\subsection{Origin and controversy of verismo}

Verismo ('realism') is traditionally regarded as an art movement in Europe at the end of the nineteenth century. The Italian term verismo has been used in literature since at least the 1870 s and was related to a fashion for scientific objectivity in low-life surroundings, notably in the work of the Sicilian writer Giovanni Verga and Luigi Capuana. ${ }^{29}$ Verismo literature was affected by the French naturalism and had a direct influence on opera in Italy at the end of the nineteenth century. In the $1890 \mathrm{~s}$, verismo began to be associated with a new style of Italian operatic composition, and the term has endured. ${ }^{30}$

Histrionic, often violent, plots characterise operatic verismo with characters drawn from daily life. Musical devices to express this include passionate declamation by soloists and emotional harmonies and melodies. ${ }^{31}$ The first example of verismo opera is often taken to be Pietro Mascagni's one-act opera Cavalleria Rusticana (Rustic Chivalry, 1890), based on a shocking story of adultery and murder among Sicilian farmers. In 1889, the opera won the first prize at a competition organised by the Milanese music publisher Edoardo Sonzogno. A companion piece by Ruggiero Leoncavallo appeared two years later in the form of Pagliacci (The Clowns, 1892), a story involving the similar elements as Cavalleria Rusticana, but set in a troupe of players, so the act of violence became the principal element - a jealous husband who

\footnotetext{
${ }^{29}$ Andreas Giger. "Verismo: Origin, Corruption, and Redemption of an Operatic Term." Journal of the American Musicological Society 60, no. 2 (August 2007): 272. ${ }^{30}$ Andreas Giger. "Verismo: Origin, Corruption, and Redemption of an Operatic Term." Journal of the American Musicological Society 60, no. 2 (August 2007): 271315.

${ }^{31} \mathrm{https}: / / \mathrm{www} \cdot$ britannica.com/art/verismo-Italian-opera
} 
kills his unfaithful wife. Both operas presented something new, particularly direct melodic and orchestral effects, not to mention the sensational dramatic shocks, and they made great impressions internationally, especially in Germany. ${ }^{32}$ Interestingly, both operas have often been performed in a so-called Cav/Pag double-bill. After Mascagni and Leoncavallo, another of the most famous composers of verismo operas was the Italian Giacomo Puccini. Some of his works are characterised by the style of verismo, such as Tosca and La bohème. Both of them depict the happy longing for love and the tragic experience in reality, which finally leads to death. However, not all of Puccini's operas are of the verismo style.

Some scholars have intimated that the term verismo itself is questionable. For example, on November 20, 1880, Verdi, in a letter to Giulio Ricordi, wrote against verismo, arguing that it was a deliberate advance of the music harmony technique at the expense of natural and straightforward melodies. ${ }^{33}$ Three years later, the philosopher Antonio Velardita was similarly opposed to this trend: "[Verismo] has destroyed everything, including the melodramma, where there is an abundance of effects, dazzling scenes, choruses, and dances interwoven with song, all designed to strike the senses; but [now] the old melody can no longer be found, only harmony." 34 Nevertheless, over time, verismo opera has often been performed and with its direct emotional connection and real-life plots, has long been popular with audiences.

The operatic style of verismo of the late nineteenth-century was distinguished by a much more declamatory type of singing than that of bel canto. The advocates of verismo vocal music often abandoned legato and instead focused on the passionate

${ }^{32}$ Carolyn Abbate and Roger Parker A History of Opera : The Last Four Hundred Years Carolyn Abbate and Roger Parker. Second ed. 2015. Print.414.

33 Andreas Giger "Verismo: Origin, Corruption, and Redemption of an Operatic Term." Journal of the American Musicological Society 60, no. 2 (2007): 290-291. doi:10.1525/jams.2007.60.2.271.

34 Andreas Giger. "Verismo: Origin, Corruption, and Redemption of an Operatic Term." Journal of the American Musicological Society 60, no. 2 (2007): 290-291. doi:10.1525/jams.2007.60.2.271. 
aspects of the music, consequently singing in an unruly and possibly

dangerous manner. While this was exciting in the moment, by adding more timbre to their voices, and not necessarily protecting it with their bodies, the vibrato tended to become unruly and unpredictable, and many singers ended up shouting. ${ }^{35}$ On the one hand, by emphasising the emotionalism of their intensely felt interpretations, the results can be exciting in the theatre. On the other hand, such a heavy mode of singing was not designed for vocal longevity, and some singers of that period had rather short careers. ${ }^{36}$ These problems became a major concern of singers. While my research has not been exhaustive, there seems to be a lack of material to guide singers in the singing techniques of verismo.

\subsection{Representative composers}

There are three crucial verismo composers: Giacomo Puccini (1858-1924), Ruggero Leoncavallo (1857-1919) and Pietro Mascagni (1863-1945). This section is a brief introduction to these composers and how they contributed to verismo.

Pietro Mascagni was born in Livorno, and his father was a baker. In 1883, He entered Milan Conservatory as a student of Amilcare Ponchielli (1834-1886), composer of the opera La Gioconda. Two years later, Mascagni was forced to leave the Conservatory because he failed to complete his assigned work, and so he left Milan without completing his studies. Initially, Mascagni earned his living by playing the double bass in the theatre and conducting touring operettas. In 1886, he and his pregnant wife Lina settled in Cerignola, Puglia, where Mascagni provided music lessons. Despite this bad start, Mascagni was the first Italian verismo composer to achieve success. He created the one-act opera Cavalleria Rusticana for a competition organised by Sonzogno in 1888-9. His next opera, L'amico Fritz (1891), is a rural comedy set in

\footnotetext{
${ }^{35}$ David L. Jones, "Understanding the Vocal Weight Factor in Singing." $<$ http://www.voiceteacher.com/vocal_weight.html $>$ (2008)

${ }^{36}$ David L. Jones, "Understanding the Vocal Weight Factor in Singing." $<$ http://www.voiceteacher.com/vocal_weight.html $>(2008)$ 
Alsace. The work is more innocent and gentler than Cavalleria Rusticana, disappointing those who expected its passion. Other relatively successful operas include Iris (1898), set in Japan; Il piccolo Marat (1921), set against the French revolution. In addition to his operas, Mascagni composed some sacred and secular choral works, songs, and some orchestral and chamber music works, most of which were not published. None of his other operas had much impact on his reputation, which was based entirely on Cavalleria Rusticana. In 1929, Mascagni succeeded Toscanini as music chief of La Scala, Milan, and his last opera, Nerone, was premiered there in 1935 but has rarely been seen since. In 1940, Mascagni conducted Cavalleria Rusticana at La Scala on the 50th anniversary of its first performance in Rome. Unfortunately, he was associated with Mussolini's Fascist regime and died in an unknown hotel in Rome shortly after the fall of Mussolini's Fascist regime in 1945.37

Known as a brilliant conductor and teacher, Mascagni was good at using the Italian style of melody in his composition, and the lyrics are harmonised with the music to fit with the plot. Convinced of the supremacy of Italian opera and the Italian language for conveying the brilliance of the vocal arts, he used the orchestra to enhance the intensity of the vocal writing. ${ }^{38}$ His representative work Cavalleria Rusticana vividly portrays each character's personality and image and profoundly reveals their complex thoughts, feelings and inner world. The vocality is emotional, interjectory and challenging in a way that that was quite different from the work of previous composers.

Ruggero Leoncavallo was born to a wealthy family in Naples. He entered his

\footnotetext{
37 "Mascagni." In Opera: The Great Composers and their Masterworks, by Joyce Bourne. Octopus Publishing Group, 2008. http://helicon.vuw.ac.nz/login?url=https://search.credoreference.com/content/entry/op gopera/mascagni/0?institutionId $=5378$

${ }^{38}$ Roger Flury "Pietro Mascagni: Time for a Reappraisal" Fontes Artis Musicae Vol. 49, No. 3 (July-September 2002), pp. 182-198
} 
hometown's Conservatory at the age of nine, where he studied for ten years. He later moved to the University of Bologna with a desire to write a trilogy about the Italian Renaissance, the Italian answer to Wagner's Der Ring des Nibelungen, that was never completed. In 1888, he moved to Paris to befriend Victor Maurel, a baritone who created Verdi's Iago and Falstaff, and who was impressed enough to persuade publishing company Ricordi to publish Leoncavallo's work. Shortly after marrying the singer Berthe Rambaud he returned to Milan. In 1890, Mascagni composed Cavalleria Rusticana, which attracted Leoncavallo, who became interested in the verismo opera. Eager to establish himself, Leoncavallo quickly composed Pagliacci to his libretto. The première in Milan in 1892 was a great success, and in 1893, the Metropolitan Opera (New York) staged Pagliacci with Mascagni's Cavalleria Rusticana. The two operas became very popular, lovingly known as "Cav and Pag" and have had many performances.

Interestingly, after this victory, Leoncavallo abandoned his planned trilogy, but when he heard that Puccini was working on La bohème, he began to create similar work himself. Although his version includes some beautiful music and realistic Paris scenes, it never becomes a serious rival to Puccini's opera. In 1906, he visited the United States and began to write operettas. He wrote many excellent songs, and the most famous of which was "Mattinata". His final effort at a comic opera was disrupted and abandoned by the First World War: he left several unfinished works when he died. Thought his compositional oeuvre is varied, his reputation is entirely based on Pagliacci. ${ }^{39}$

Leoncavallo made a significant contribution to verismo opera, but his material and

39 "Leoncavallo." In Opera: The Great Composers and their Masterworks, by Joyce Bourne. Octopus Publishing Group, 2008.

http://helicon.vuw.ac.nz/login?url=https://search.credoreference.com/content/entry/op gopera/leoncavallo/0?institutionId $=5378$ 
importance are yet to be researched and documented..$^{40}$ Most of his opera scripts were created by himself, and his works are innovative in both dramatic structure and music. The idea of commedia dell'arte (the play within the play) is a brilliant theatrical device that highlights the tragic plots and serious subject, giving the traditional comedy forms a more profound expression.

Giacomo Puccini was born in Lucca in 1858, about 12 miles from Pisa. Both organists and choirmasters at Lucca's cathedral, his great-grandfather, was an associate of the Accademia Filarmonica of Bologna, and his grandfather, Domenic, wrote an opera that was highly praised by Paisiello. Giacomo was one of seven children, and when his father died in 1863, his equally music-loving mother, Albina, was determined to follow the family's musical tradition and became an organist in the church. Puccini learned to sing and play the organ from an uncle, went to the city's music school (the Istituto Musicale Pacini, where his father had been a director), graduated in 1880 and wrote a mass called Messa di Gloria. Following that he went to the Milan Conservatory, where he studied with Ponchielli and others and shared a room with Mascagni.

Puccini wrote his first opera, Le villi, in 1883, and entered the competition organised by Sonzogno, which was won five years later by Mascagni's Cavalleria Rusticana. ${ }^{41}$ Le villi was rejected for his illegible handwriting, but some of his friends arranged a performance in Milan in 1884 that caught the attention of young composer Giulio Ricordi, who published many Verdi's works. Ricordi must have been impressed as he

${ }^{40}$ The lives and work of both Mascagni and Leoncavallo have not been researched thoroughly. What is particularly missing is a critical assessment of their music. 41 "Italian publishing house, active in music from 1874 under Edoardo Sonzogno (1836-1920), who ran competitions for one-act operas four times between 1883 and 1902, winning Cavalleria rusticana in the process. He became the publisher not only of Mascagni but also of Leoncavallo, Giordano and Cilea." "Sonzogno." In The New Penguin Dictionary of Music, by Paul Griffiths. Penguin, 2006.

http://helicon.vuw.ac.nz/login?url=https://search.credoreference.com/content/entry/pe nguinmusic/sonzogno/0?institutionId $=5378$ 
paid him a deposit to concentrate on his next composition, the opera $\operatorname{Edgar(1889).}$ Edgar did not have a positive reception, but his Manon Lescaut had a successful premiere in Turin in 1893, and Puccini never looked back from then. On the proceeds of his compositions and the rights, he was able to build a villa at Torre del Lago, where he wrote the rest of his works. Ricordi recommended to him as librettists Luigi Illica and Giuseppe Giacosa, who then wrote the scripts for his next three operas, $L a$ bohème, Tosca, and Madama Butterfly. These three operas quickly became, and remained, the worldwide favourites in the world and made him Italy's leading composer.

Puccini had a chequered personal life. In 1886, he lived with a married woman, Elvira Geminiani, and they had a son. She married Puccini shortly after her husband's death. It was not a happy marriage because he was often unfaithful, and she was jealous. The most notorious incident of the period was the suicide of a former maid in the Puccini family: Elvira was convinced that her husband had an affair with the girl and that she was pregnant with his child, but an autopsy proved that was not true. Unfortunately, the scandal and lawsuit took much of his time, and Puccini's next opera, La fanciulla del West (The Girl of the Golden West), did not appear until 1910. During the First World War, Puccini created La Rondine (The Swallow) and three one-act operas that formed Il trittico: Il tabarro, Suor Angelica and the comedy Gianni Schicchi, and all premiered in post-war New York. Puccini began to write his last opera Turandot in 1920. He was a chain smoker for years and had developed throat cancer by this time. Even though submitting to the new radiation therapy, he died in 1924, while receiving treatment in a Brussels hospital, leaving his last opera Turandot unfinished. ${ }^{42}$

Puccini loved blood sports and motor cars, but he was also a sensitive man, often

42 "Puccini." In Opera: The Great Composers and their Masterworks, by Joyce Bourne. Octopus Publishing Group, 2008. http://helicon.vuw.ac.nz/login?url=https://search.credoreference.com/content/entry/op gopera/puccini/0?institutionId $=5378$ 
lonely and melancholy, much of which is expressed in his operas. He was a master of melodies, producing impressively beautiful arias, duets and ensembles in all his operas, drawing on the influence of the French master Massenet and the German idiom represented by Wagner to form his style. Like all the best opera composers, he had a natural theatrical instinct for what could and could not be performed on stage. Puccini has always been the most famous composer in the public mind, but he is less popular among critics, who are reluctant to praise him as a serious composer and accuse him of manipulating audiences' emotions. Times have changed, and Puccini is increasingly regarded as the most talented composer and dramatist of the highest calibre. Moreover, if he is popular with the public and sells seats in the theatre, there is no reason to laugh at him or his operas. ${ }^{43}$

Puccini's operas are a vital part of the international standard repertoire. Some of his operas are based on the real-life conditions of the underclass in real life, showing concern for the fate of the ordinary people in society, which is a typical feature of verismo. His operatic structure is characterised by simplicity which conveys the dramatic appeal quickly and directly: however, he was also interested in experimenting with forms and various theatrical devices - including the motif to develop ideas beyond the story and text. ${ }^{44}$ Moreover, he focused on the integration of orchestral and vocal music which communicate directly with the audience. ${ }^{45} \mathrm{He}$ was very good at creating female characters in his operas: Liu from Turandot, Cio-Cio-san from Madama Butterfly, Magda from La Rondine, Mimì and Musetta from La Bohème, Tosca from Tosca are unforgettable. In addition, he liked to adopt Oriental elements by changing the folk songs of various countries, and this can be seen in his

\footnotetext{
43 "Puccini." In Opera: The Great Composers and their Masterworks, by Joyce Bourne. Octopus Publishing Group, 2008. http://helicon.vuw.ac.nz/login?url=https://search.credoreference.com/content/entry/op gopera/puccini/0?institutionId $=5378$ ${ }^{44}$ Julian Budden Puccini: His Life and Works, New York: Oxford University Press, 2002

${ }^{45}$ Julian Budden, Ibid.
} 
Madama Butterfly and Turandot.

\subsection{Embodiment of verismo singing}

In contrast to bel canto operas, the singing and movement of verismo operas are about life-like and quasi-real representations of the emotional content that the singers are singing. As mentioned previously, the words and the story are continuous, there is no repetition, and it is as if the singer is telling through the story. The singer is continuously reacting to the changing emotional content of the words, and yet still must sing well. If the singer is too involved in the emotion, it would be too easy to scream or shout which has an adverse effect on the voice. Therefore, according to my singing experience, the body and the engagement of the muscles must be carefully trained to react to the much more direct and possibly forceful vocal line. In addition to the intense emotions, the orchestra is bigger, and so the singer must focus on projecting the voice and the text. This requires a lot of bodily counterbalances, much more than singing bel canto. Training this helps their brain to hear the right sound, declaiming the text at pitch is very helpful to get the correct forward placement and projection, keeping the sound more forward than nasal and raising the soft palate/ tensor muscles. This placement requires much more engagement of the body to balance the forward sound - the true manifestation of chiaroscuro- light/dark- in the vocal sound. ${ }^{46}$

\section{Analysis of verismo vocal recordings}

This section is a very brief analysis of several successful singers and their verismo roles and works. I chose these singers as they were successful, unlike many others, and listened to their audio recordings in order to inform myself of their vocal health and technique.

\footnotetext{
${ }^{46}$ As related to me by Dr Margaret Medlyn.
} 
Some important singers in the early twentieth century were able to incorporate and develop singing techniques which combined facets of bel canto techniques with the more direct, speech-like and straightforward singing of verismo. Most prominent amongst these singers were soprano Rosa Ponselle (1897-1981), tenor Enrico Caruso 1873-1921, and baritone Titta Ruffo (1877 - 1953). ${ }^{47}$

Enrico Caruso was one of the most famous dramatic tenors in history. He sang in local churches, and his unique vocal potential caught the attention of Guglielmo Vergine, who enrolled him as a student. Caruso spent three hard years working on exercises, and then he started on learning repertoire. He made his debut in Morelli's L'amico Francesco in Naples, Italy, in 1894, and then performed in small theatres, albeit with varying degrees of success. In 1897, he made his Palermo debut in Ponchielli's La Gioconda. The following year, he was acclaimed for his performance as Loris in the debut of Giordano's Fedora in Milan. It marked the start of Caruso's international career, which took him to Buenos Aires, Rome, Monte Carlo, London and New York. From 1902 to 1920, every season he performed at the Metropolitan Opera in New York earned him his greatest fame. In 1902, he recorded ten memorable arias for the Milan Gramophone Company, which achieved unprecedented commercial success and created the first international demand for records. It was this combination of power projection and gentle lyric poetry, and his mastery of bel canto and the imaginative details he brought to the nuances of music and words, that made him famous. ${ }^{48}$

Caruso performed French and Italian lyric repertoire, as well as lighter operas, with his excellent sound quality, mezza voce (especially in the early days), based on

\footnotetext{
${ }^{47}$ Michael Scott. The Record of Singing, Gerald Duckworth \&Co.Ltd, 1991, 103-164.

${ }^{48}$ Jon Tolansky. "Caruso, Enrico." In The Oxford Companion to Music. : Oxford University Press, https://www-oxfordreferencecom.helicon.vuw.ac.nz/view/10.1093/acref/9780199579037.001.0001/acref9780199579037-e-1192.
} 
mastery of rare legato and portamento. ${ }^{49}$ One example of a verismo aria that he sang with some bel canto techniques is the role of Pagliacci: "Recitar!...Vesti la guibba" composed by Ruggero Leoncavallo (see link in footnote).$^{50}$ One of the characteristics of bel canto is legato singing. Articulation of each letter and the legato connection between the notes that Caruso had mastered was remarkable. Each letter changes to the second letter in a round way and seems to be seamless. His voice sounds easy, and when he started a tone, his voice was soft but sturdy; nevertheless, he never let consonants affect the vowels. Caruso sings a natural, relaxed placement, excellent messa di voce.

Rosa Ponselle was an American operatic soprano of Italian descent. She began singing in movie theatres and vaudeville shows and studied singing with William Thorner and Romano Romani, who recommended her to Caruso. His influence led to her première at the Metropolitan Opera in New York as Leonora in La forza del destino (1918), one of the most sensational events in the Metropolitan's history because of the reception she got from the audience and she quickly became one of the preeminent sopranos of the day. Over the next nineteen years, she performed 22 theatrical roles at the Metropolitan Opera, notably Norma, Donna Anna, Violetta, Rachel (La Juive) and Santuzza, and she had similar successes at Covent Garden. Her beautiful appearance and elegant performance are matched by the richness of tone, expressiveness and virtuosity that can be heard on her recordings. ${ }^{51}$ Ponselle had a

${ }^{49}$ Rodolfo Celletti, and Alan Blyth. "Caruso, Enrico." Grove Music Online. 11 Feb. 2013; Accessed 15 Dec. 2019. https://www-oxfordmusiconlinecom.helicon.vuw.ac.nz/grovemusic/view/10.1093/gmo/9781561592630.001.0001/om o-9781561592630-e-1002234670.

${ }^{50}$ Viva Enrico Caruso: 25 Great Opera Arias \& Songs. Recorded January 1, 2003. Hänssler Classic, 2003, Streaming Audio. https://search.alexanderstreet.com/view/work/bibliographic_entity\%7Crecorded_cd\% 7 C4033976.

${ }^{51}$ Jon Tolansky. "Ponselle [Ponzillo], Rosa (Melba)." In The Oxford Companion to Music. : Oxford University Press, https://www-oxfordreferencecom.helicon.vuw.ac.nz/view/10.1093/acref/9780199579037.001.0001/acref9780199579037-e-5280. 
voice of great colour: famed for her extensive range, her delicate pianissimi, her clarity of tone, and her emotional expressiveness, Ponselle worked continually during her performing career to sustain and develop her vocal gift. Her incredible musical control on stage belied the terrible stage fright that plagued her ever since her Metropolitan debut. She studied her roles carefully, often basing her interpretations not solely on the libretto, but on original stories and books. ${ }^{52}$

Lesser known, Titta Raffo's voice was known for its resonance, strength, range and almost tenorial range of high notes, and its purity, warmth and breath control. It also had a typically dark, sometimes melancholic colour, notably in Thomas' Hamlet and Verdi. He was an energetic, energetic actor, and his voice was correspondingly dramatic and powerful, though sometimes raw and loud. His great success in operas such as L'Africaine, La Gioconda, Pagliacci and Il barbiere di Siviglia, eventually revolutionised Italian taste for baritone singing, moving away from the elegant, classical 19th-century tradition to an unpolished, radical style. Many of his recordings have been re-recorded on CDS, giving a good sense of his range and power. ${ }^{53}$

\section{Applying bel canto concepts to verismo}

Three arias will be taken as examples to investigate and articulate the difficulties in performance, both technical and dramatic. For each of these case studies, after a brief story synopsis, I then describe my learning process of the three arias.

\footnotetext{
${ }^{52}$ https://www.fembio.org/english/biography.php/woman/biography/rosa-ponselle/ Accessed 10/2/2020.

${ }^{53}$ Rodolfo Celletti, and Alan Blyth. "Ruffo, Titta." Grove Music

Online. 2001; Accessed 15 Dec. 2019. https://www-oxfordmusiconlinecom.helicon.vuw.ac.nz/grovemusic/view/10.1093/gmo/9781561592630.001.0001/om o-9781561592630-e-0000024104.
} 


\subsection{Case study from Don Pasquale 'Quel guardo il cavaliere'}

Don Pasquale was Donizetti's last comic opera to remain in a regular repertoire in the first half of the 19th century. It was written for Paris in 1843 and was an instant success. It was seen in London that same year and in New Orleans in 1845..$^{54}$

Opera Synopsis: Pasquale (bass), an old bachelor, disapproves of his current heir, his nephew Ernesto (tenor) being in love with Norina (soprano), a young widow, so he decides to disinherit Ernesto. Dr Malatesta (baritone) supports Ernesto and Norina secretly. He suggests to Pasquale to marry his "sister Sofronia", who is Norina in disguise. Malatesta persuades Norina to marry Don Pasquale so she could be closer to Ernesto. The deed of marriage is prepared by 'a Notary' (Malatesta's cousin), who gives half of Pasquale's fortune to his bride. Pasquale soon regrets his decision, as Sofronia's personality changes entirely overnight, and she spends Pasquale's money at a rapid rate. After she deliberately hints at a date with another man, Pasquale consults Malatesta. Malatesta encourages him to catch her and her lover in the garden. Ernesto sings a serenade when he waits for Norina, and they sing a romantic duet. The angry Pasquale grabs them and is persuaded by Malatesta to annul the marriage, which Pasquale is only too happy to do. When all is revealed, he was so relieved to be free that he forgives all their deceit and give his blessing to Norina and Ernesto. ${ }^{55}$

The aria 'Quel guardo cavaliere' is from Act I Scene II. When the curtain rises, Norina is reading a sentimental novel. She throws it aside to show the audience her flirtatious

54 "Donizetti." In Opera: The Great Composers and their Masterworks, by Joyce Bourne. Octopus Publishing Group, 2008.

http://helicon.vuw.ac.nz/login?url=https://search.credoreference.com/content/entry/op gopera/donizetti/0?institutionId $=5378$

55 "Donizetti." In Opera: The Great Composers and their Masterworks, by Joyce Bourne. Octopus Publishing Group, 2008. http://helicon.vuw.ac.nz/login?url=https://search.credoreference.com/content/entry/op gopera/donizetti/0?institutionId $=5378$ 
and lively nature. Because of the many different sections of this aria, I use a metronome all the time when I practice, making sure the rhythm is consistent.

One of the difficulties with this aria for me is the complexity of the lyrics, including the number of double consonants. I find that singing complex lyrics can easily strain my jaw, and therefore I pay attention to the relaxation of my chin while singing. Tapping the chin with an index finger while singing is a technique to relax the chin; otherwise, the jaw muscle will get stronger and stronger. As a bel canto aria, here I have focused on my beauty and consistency of tone, and look for opportunities to sing messa di voce. In the cabaletta, I focus on the tuning and accuracy of the coloratura. As there are a lot of long notes in the passaggio area I must take care to keep my throat open and to keep the air moving forward all the time. Every note should be vibrating from the beginning of the aria: the 'rolled'r in the aria helps a lot with the airflow and keeps the vibrato fluid and even. The air should always be flowing, and never held as this causes tension in the muscles and a build-up of carbon dioxide in the body. Singing with the feeling of crying (laryngeal tilt) helps stabilise all notes, particularly the high notes in the passaggio and also I focus on getting the pitch correct. I use the same bodily engagement when changing pitches, trying not to push or move my tongue or any other part inside the vocal tract. When I have practised in these physical needs, I focus on expressing the emotional journey and become alive and responsive to the text.

\subsection{Case study from I Pagliacci 'Stridono lassù'}

Leoncavallo wrote I Pagliacci with a Prologue and two acts after the success of Mascagni's one-act Cavalleria Rusticana. After I Pagliacci debuted in Milan in 1892, Leoncavallo became famous.

Opera Synopsis: A singing and acting troupe comes to perform in a Calabrian village. Nedda (soprano), the wife of the colonel Canio (tenor), has a secret affair with 
villager Silvio (baritone). The player Tonio (baritone) also expresses his love for Nedda but is rejected and so bears a grudge. Tonio knows the news that Silvio plans to elope with Nedda and he informs Canio. By the time Canio arrives, Silvio has fled. Canio threatens Nedda to reveal the lover, but Nedda says nothing. The stage is about to open but Canio takes the stage to keep his anger in check. The plot of the play is the same as what is happening in reality. Nedda plays a young woman who falls in love with a village youth and is about to elope when her husband discovers her. At this time, Canio has muddled reality with stage performance. He is unable to control himself and pulls out a knife to kill Nedda. Silvio comes to the rescue but also is stabbed by him. The villagers surround Canio. He drops the dagger on the stage and stays there for a moment. Then he says to the audience: Comedy is over ( $L a$ commedia e finita). ${ }^{56}$ A striking feature of the opera is the drama within the drama of the second act. The plot of the play is so similar to what happens between the hero and the heroine that the hero forgets he is acting in a play. His anger boiled over into tragedy. ${ }^{57}$

From Act I, Nedda worries about that if Canio knows she had betrayed him, imagining that the consequences would be terrible. However, when she watches birds whirling in the sky, she recalls her mother, who used to predict good fortune and understood bird singing. She admires the birds for flying freely in the sky and longs for the love between herself and her lover to be as free as a bird, and she begins to sing the aria 'Stridono lassù'. The aria expresses her anxiety and longing for a new love. The beginning is a prelude to the ten bars, and the sixteenth notes, like a bird in flight, also express Nedda's happy mood at this moment.

56 "Leoncavallo." In Opera: The Great Composers and their Masterworks, by Joyce Bourne. Octopus Publishing Group, 2008.

http://helicon.vuw.ac.nz/login?url=https://search.credoreference.com/content/entry/op gopera/leoncavallo/0?institutionId $=5378$

${ }^{57}$ Michele Girardi. "Pagliacci." In The Grove Book of Operas. : Oxford University Press, 2006. https://www-oxfordreferencecom.helicon.vuw.ac.nz/view/10.1093/acref/9780195309072.001.0001/acref9780195309072-e-195. 
For me the most challenging part of this piece is the fast singing of many high notes on the passaggio. These high notes raise the larynx quickly, which can make my voice sound thin because it cuts out the lower harmonics. As a result, my throat feels very tired and loses the timbre. If I push the high notes, do not keep the soft palate high or do not have enough air to support the singing, my high notes tend to become flat. Therefore, I drop my jaw and keep the throat open all the time, and engage my appoggio- working outwards on the intercostal muscles to prevent the diaphragm from collapsing upwards. Also, I need to keep the mid-tongue flopping forward and soft palate high. I use 'rolled' $r$ instead of the text to practice making air run through these high notes. The 'rolled'r in the lyrics is beneficial when singing the text to remind me to keep the air flowing. My teacher Margaret Medlyn told me chest resonance is effectively bringing the low harmonics into the complete vocal sound. On the contrary, head resonance is high harmonics. Using both chest resonance and head resonance can not only avoid a very sharp sound but also help to produce a harmonious and balanced sound.. The important thing is that performers need much air to move along with their singing. When I practise these physical necessities, I need to think about the emotional journey. This is difficult as I get involved in the emotion, so I must anchor my core muscles very low in my body, and use my ribs to keep the low resonances, and the declaiming quality in my voice. At the same time, I think of legato and tuning, all bel canto attributes.

\subsection{Case study from Madama Butterfly 'Un bel di vedremo'}

Madama Butterfly was the third and last Puccini opera to be written by Luigi Illica and Giuseppe Giacosa as librettists. They based the story on a play by American David Belasco (1853-1931). Although Madama Butterfly's premiere at La Scala in 1904 was a failure, it regained popularity over the next few years after Puccini made various modifications. Cio-Cio-San (called Butterfly) is the only heroine in this opera. 
Her character develops from an innocent little girl to a mature, self-sacrificing mother. ${ }^{58}$

Opera Synopsis: The story is set in Nagasaki, Japan, in the early twentieth century. The American officer Pinkerton (tenor) will marry a 15-year-old Japanese bride. The bride Cio-Cio-San (soprano) falls in love with the American officer so profoundly that she gives up her religion and converts to Christianity. Her uncle, the Bonze (bass), curses her for betraying her religion, and the rest of the family reject her on her wedding. At the wedding night, Butterfly professes her love for him, and Pinkerton enjoys the adoration of his child bride and makes her pregnant. However, Pinkerton soon returns to the United States, where he marries another wife. Three years later, Pinkerton returns to Nagasaki, Japan, with his American wife Kate to bring his son back to the United States. Butterfly knows the truth. When Pinkerton arrives, he finds that Butterfly has killed herself with her father's ceremonial dagger. ${ }^{59}$

The aria 'Un bel di vedremo' is one of the most famous arias. In Act II of the opera, Pinkerton returns to the United States. Cio-Cio-San's maid thinks he would not return, but the faithful Cio-Cio-San keeps dreaming of the happy moment: when Pinkerton will return in a bright morning on a warship. She faces the sea and sings the aria 'Un bel di vedremo'. This aria mainly describes the Cio-Cio-San's beautiful fantasy, so the emotions expressed in the singing should be beautiful expectations, urgent excitement and hope.

\footnotetext{
58 "Puccini." In Opera: The Great Composers and their Masterworks, by Joyce Bourne. Octopus Publishing Group, 2008. http://helicon.vuw.ac.nz/login?url=https://search.credoreference.com/content/entry/op gopera/puccini/ $/ 0$ institutionId $=5378$

${ }^{59}$ Bourne, Joyce. "Madama Butterfly." In A Dictionary of Opera Characters. : Oxford University Press, 2008. https://www-oxfordreferencecom.helicon.vuw.ac.nz/view/10.1093/acref/9780199548194.001.0001/acref9780199548194-e-1157.
} 
One difficulty of this song is its rhythm. The $2 / 4$ beat starts from the lyrics "Piangi? Perche?". From "Un bel di vedremo...", that is 3/4 beat from "metto la sul ciglio del colle" back to $2 / 4$ beat. However, from "Chi Sara? Chi Sara?" Puccini used the 4/8 beat. At first, I was confused by these different beats. Nevertheless, there is the term Lo stesso movimento above $4 / 8$ on the staff. Understanding the meaning of this musical term helps singers sing to the right beat. In addition, I advise singers not to listen to other singers' recordings until they have learned the new song entirely correctly because it may interfere with learning the right rhythm. Using metronomes is the right way to learn.

Vocally, this aria is easier that Stridono lassù as it lies within a smaller tessitura, and the build-up to the high notes is more vocal - in other words, it is as if Puccini understands the voice better. Nonetheless, I need to be careful that all the singing is on the body with my core muscles engaged. This gives me the opportunity to change the degree of laryngeal tilt if I want to be particularly expressive or quieter. I need to remember that Cio-Cio San is still really a girl.

The last long B-flat note presents a challenge. To practice this long note, I sing it as part of my daily warm-up. While singing, the whole body should be fully engaged in the singing rather than shouting through the voice: in other words, I must have maximum laryngeal tilt, and cannot push too much air pushing myself out of tilt. The soft palate must be lifted when singing a high note. I practice this step by step to make sure the notes are stable. I find my body has to work much harder here than in the Donizetti. My ribs work harder as well as my pelvic floor muscles. When I am ready, I plot my emotional journey according to my responses to the text.

\section{Conclusion}

Within the confines of my exegesis, I have laid out the basic precepts of the bel canto singing technique and discussed the embodiment and application of those techniques. 
In doing the same for the verismo movement, I have articulated the vital need for the bel canto technique, and particularly the need for an enhanced embodiment, and engagement of muscles. In addition, I have articulated the challenges for a Mandarin speaker to sing Italian well in a bel canto manner. I believe this be very useful to other Mandarin speakers.

I have surveyed the important composers of bel canto and verismo, and also briefly looked at successful singers of the verismo period. My descriptions of my process of learning the representative arias have helped me articulate and differentiate what I have in the past done without analysis of my practice habits.

Through my investigations, I conclude that it is essential for a singer to have proper and thorough training in the bel canto techniques to sing verismo opera safely. In addition, the singer must be prepared to engage their body more to support the heightened and overt emotional singing required, and to support the declamato quality needed for the text.

My research not only helps me to have a better understanding of the concept of bel canto and verismo but also to apply the singing techniques I learned in vocal lessons to performance to my repertoire. With systematic training of bel canto in China and New Zealand, I can improve and learn about singing verismo opera excellently and this process will play a crucial role in my future career. I believe my research will provide reference and help for young singers. 


\section{Bibliography}

"Bel Canto." Britannica Online Academic Edition (2019): Encyclopædia Britannica, Inc. Web.

"Bellini." In Opera: The Great Composers and their Masterworks, by Joyce Bourne. Octopus Publishing Group, 2008. http://helicon.vuw.ac.nz/login?url=https://search.credoreference.com/content/e ntry/opgopera/bellini/0?institutionId $=5378$

"Castrato [It.]." In The Harvard Dictionary of Music, edited by Don Michael Randel. 4th ed. Harvard University Press, 2003. http://helicon.vuw.ac.nz/login?url=https://search.credoreference.com/content/e ntry/harvdictmusic/castrato_it/0?institutionId $=5378$

"Donizetti." In Opera: The Great Composers and their Masterworks, by Joyce Bourne. Octopus Publishing Group, 2008. http://helicon.vuw.ac.nz/login?url=https://search.credoreference.com/content/e ntry/opgopera/donizetti/0?institutionId $=5378$

"Duprez, Gilbert (Louis)." In The New Penguin Dictionary of Music, by Paul Griffiths. Penguin, 2006.

http://helicon.vuw.ac.nz/login?url=https://search.credoreference.com/content/e ntry/penguinmusic/duprez_gilbert_louis/0?institutionId=5378

"Leoncavallo." In Opera: The Great Composers and their Masterworks, by Joyce Bourne. Octopus Publishing Group, 2008. http://helicon.vuw.ac.nz/login?url=https://search.credoreference.com/content/e ntry/opgopera/leoncavallo/0?institutionId $=5378$

"Mascagni." In Opera: The Great Composers and their Masterworks, by Joyce Bourne. Octopus Publishing Group, 2008. http://helicon.vuw.ac.nz/login?url=https://search.credoreference.com/content/e ntry/opgopera/mascagni/0? institutionId $=5378$

"Puccini." In Opera: The Great Composers and their Masterworks, by Joyce Bourne. Octops Publishing Group, 2008. 
http://helicon.vuw.ac.nz/login?url=https://search.credoreference.com/content/e ntry/opgopera/puccini/0?institutionId $=5378$

"Sonzogno." In The New Penguin Dictionary of Music, by Paul Griffiths. Penguin, 2006 .

http://helicon.vuw.ac.nz/login?url=https://search.credoreference.com/content/e ntry/penguinmusic/sonzogno/0?institutionId $=5378$

Apel, Willi. Harvard Dictionary of Music. $2 \mathrm{~d}$ ed., rev. and enl. Cambridge, Mass: Belknap Press of Harvard University Press, n.d.

Abbate, Carolyn and Parker, Roger. A History of Opera; The Last Four Hundred Years, New York: Penguin Group, 2012.

Ashbrook, William, and Powers, Harold, Puccini's Turandot the End of the Great Tradition. S.1.], 2014. Web.

Baird, Julianne. "The Bel Canto Singing Style." In A Performer's Guide to Seventeenth-Century Music, edited by Carter Stewart, by Kite-Powell Jeffery. Indiana University Press, 2012. http://www.jstor.org/stable/j.ctt16gzcwn.

Bellingham, Jane. "Verismo." The Oxford Companion to Music (2011): The Oxford Companion to Music. Web.

Bourne, Joyce. "Madama Butterfly." In A Dictionary of Opera Characters. : Oxford University Press, 2008. https://www-oxfordreferencecom.helicon.vuw.ac.nz/view/10.1093/acref/9780199548194.001.0001/acref9780199548194-e-1157.

Bourne, Joyce. "Pasquale, Don." In A Dictionary of Opera Characters.: Oxford University Press, 2008. https://www-oxfordreferencecom.helicon.vuw.ac.nz/view/10.1093/acref/9780199548194.001.0001/acref9780199548194-e-1463.

Budden Julian The New Grove Masters of Italian Opera (with others), New York, W.W. Norton, 1981; John Rosselli, Music and Musicians in NineteenthCentury Italy. Portland (OR): Amadeus Press, 1991.

Budden, Julian Puccini: His Life and Works, New York: Oxford University Press, 2002. 
Celletti, Rodolfo, and Blyth, Alan. "Caruso, Enrico." Grove Music Online. 11 Feb. 2013; Accessed 15 Dec. 2019. https://www-oxfordmusiconlinecom.helicon.vuw.ac.nz/grovemusic/view/10.1093/gmo/9781561592630.001.0 001/omo-9781561592630-e-1002234670.

Celletti, Rodolfo. A History of Bel Canto, Oxford, Clarendon Press, 1991.

Crutchfield, Will. "The Bel Canto Connection: What Are the Difference between Singing Handel and Singing Rossini, Bellini and Donizetti?" Opera News 62.1 (1997): 30-\&. Web.

Elliott, Martha. Singing in Style: A Guide to Vocal Performance Practices. Yale University Press, 2006. http://www.jstor.org/stable/j.ctt32brkx.

Flury, Roger "Pietro Mascagni: Time for a Reappraisal” Fontes Artis Musicae Flury, Roger, "Pietro Mascagni: Time for a Reappraisal" Fontes Artis Musicae Giger, Andreas. "Verismo: Origin, Corruption, and Redemption of an Operatic Term." Journal of the American Musicological Society 60, no. 2 (2007): 271315. doi:10.1525/jams.2007.60.2.271. Kennedy, Michael, and Bourne, Joyce. "Verismo." The Oxford Dictionary of Music 2012.Web.

Gioacchino (Antonio), Rossini, From Britannica Concise Encyclopedia, by Encyclopaedia Britannica. Britannica Digital Learning, 2017. http://helicon.vuw.ac.nz/login?url=https://search.credoreference.com/content/e ntry/ebconcise/rossini_gioacchino_antonio/0?institutionId=5378

Girardi, Michele. "Pagliacci." In The Grove Book of Operas. : Oxford University Press, 2006. https://www-oxfordreferencecom.helicon.vuw.ac.nz/view/10.1093/acref/9780195309072.001.0001/acref9780195309072-e-195.

Jones, David L. "Understanding the vocal weight factor in singing." $<$ http://www.voiceteacher.com/vocal_weight.html > (2008)

Medlyn, Margaret, Embodying Voice, Singing Verdi, Singing Wagner, Routledge New York, 2019.

Osborne, Richard. Rossini: His Life and Works. 2nd ed. New York: Oxford University Press, 2007. Oxford Scholarship Online, 2011. doi: 
10.1093/acprof:oso/9780195181296.001.0001.

Pan, Keke, http://www.oxiang.com/music/20170813/61171.html

Pleasants, Henry, The Great Singers, New York: Simon and Schuster, 1966.

Riggs, Geoffrey S., The Assoluta Voice in Opera 1797 - 1847, London: McFarland, 2003.

Rutherford, Susan, The Prima Donna and Opera 1815-1930, Cambridge: Cambridge University Press, 2006.

Scott, Michael, The Record of Singing, Gerald Duckworth \&Co.ltd, 1991.

Siff, Ira. "Scotto Voce." Opera News 64.7 (2000): 18-24. Web.

Smart, Mary Ann. "Donizetti, (Domenico) Gaetano (Maria)." In The Oxford Companion to Music.: Oxford University Press, https://www.oxfordreference.com/view/10.1093/acref/9780199579037.001.00 01/acref-9780199579037-e-2025.

Stark, James, Bel Canto: A History of Vocal Pedagogy, Toronto: University of Toronto Press, 1999.

Sundberg, Johan The Science of the Singing Voice, Northern Illinois University Press 1987

Timberlake, Craig. "Verismo Voices." Journal of Singing - the Official Journal of the National Association of Teachers of Singing 53, no. $1(09,1996)$ : 33-35. https://search.proquest.com/docview/1399506?accountid=14782.

Toft, Robert, Bel Canto: A Performer's Guide, USA: Oxford University Press, 2012. Tolansky, Jon. "Caruso, Enrico." In The Oxford Companion to Music.: Oxford University Press, https://www-oxfordreferencecom.helicon.vuw.ac.nz/view/10.1093/acref/9780199579037.001.0001/acref9780199579037-e-1192.

Tolansky, Jon. "Ponselle [Ponzillo], Rosa (Melba)." In The Oxford Companion to Music. : Oxford University Press, https://www-oxfordreferencecom.helicon.vuw.ac.nz/view/10.1093/acref/9780199579037.001.0001/acref9780199579037-e-5280.

Viva Enrico Caruso: 25 Great Opera Arias \& Songs. Recorded January 1, 2003. 
Hänssler Classic, 2003, Streaming Audio.

https://search.alexanderstreet.com/view/work/bibliographic_entity\%7Crecorde d_cd\%7C4033976.

Vol. 49, No. 3 (July-September 2002), pp. 182-198

\section{Glossary}

Coloratura: a soprano who sings elaborate ornamentation containing improvised or written out running passages and trills. This style was common in the 18th and 19th centuries in such arias as Wolfgang Amadeus Mozart's The Magic Flute Queen of the Night. These arias usually require a soprano with an extended high range.

Da capo: a directive to the performer to go back to the beginning of the composition. This directive is abbreviated: D.C.

Legato: a directive to perform the indicated passage of a composition in a smooth, graceful, connected style, as opposed to staccato which means detached. It is often indicated by a slur over the effected notes or as an accent mark with a line over the notes to be performed in this manner.

Lo stesso movimento: the same tempo. An indication in a composition that directs that the beat remains constant when the meter changes. In the case of $2 / 4$ to $6 / 8$, the meter is still counted with two beats per measure but the tempo or speed of the beat stays the same. All that has changed is the division of the beat (often referred to as subdivision) from the duplets of the $2 / 4$ to the of the $6 / 8$.

Messa di voce: the gradual swelling and diminishing of sound produced by the voice that gives shape to a long note. This technique has been used with instruments as well, but is primarily a vocal instruction.

Passaggio: is used in classical singing to describe the transitional area between vocal registers.

Sostenuto: is a direction to performers to play smoothly and in a sustained manner. 